\title{
Situating Subjectivity between Humanism and Anti-Humanism: An Allegory of Existential Faith in Caifás
}

\section{Daryl R. Hague}

The work of Panama's José de Jesús "Chuchú" Martínez fits comfortably among the Latin American dramas of the 1950s and 1960s that moved away "from the social problems of a Spanish American reality to universal metaphysical preoccupations" (Woodyard 186). In Chuchú's work, those preoccupations are principally existential. Indeed, his work has been praised for evoking existential anguish in the face of a meaningless universe (Quackenbush 55-56; Rodríguez-Sardiñas and Suárez Radillo 372; Solórzano 156). Existential anguish certainly appears in Chuchú's 1961 drama Caifás, but Caifás goes far beyond such anguish by contributing to recent discussions about subjectivity. That is, Caifás expresses support for "situated subjectivity" (Kruks 11), an essentially existentialist subjectivity that occupies a middle ground between humanism and anti-humanism. Caifás supports this subjectivity through an arresting allegory of faith. This paper reviews existentialist, anti-humanist and humanist accounts of subjectivity, then demonstrates how Caifás creatively employs an allegory of faith to ground the human agency required for situated subjectivity.

To begin, a brief plot summary is in order. Caifás unfolds as characters confront the problem of evil: Jewish leader Caiaphas, recognizing that his people cannot reconcile the coexistence of human suffering and a just God, invents a way for them to do so. Caiaphas' plan involves a big lie in which he frames a Nazarene "charlatan" named Jesus (Martínez 80). Interestingly, Caiaphas' framing of Jesus does not simply involve accusing Jesus of a crime. Instead, Caiaphas ensures that Jesus satisfies all messianic prophecies; he then manipulates the Jewish community to demand Jesus' death. After doing so, Caiaphas convinces his people that their miserable lives reflect a just God's punishment for killing the Messiah. 


\section{Existential Redemption}

Caifás ends as Caiaphas learns that his big lie is absolutely successful. Specifically, a new widow named Martha appears at the temple. Martha was a member of the crowd who demanded Jesus' crucifixion. Her appearance at the temple, however, has nothing to do with that incident. Instead, she has come to complain that in addition to her husband's recent death, her only son has just died. When the assistant priest - at Caiaphas' behest - tells her that Jesus was the Son of God, she responds as follows: "And I helped to kill him! No wonder my own son died, since I was killing the Son of God at the time. Now I see! Oh, forgive me, Lord!" (Martínez 95).'

Martha's statement shows that Caiaphas' big lie has successfully redeemed God in the people's eyes. Nevertheless, God remains unredeemed - not demonstrably just - in Caiaphas' own view. This view reflects that of many existentialist thinkers, who argue that God's existence is irrelevant to the human condition. The world, in other words, contains no givens other than one's own existence. This lack of a pre-ordained self or purpose explains Sartre's oft-repeated maxim that "existence precedes essence" (Sartre, "Humanism" 349). Rather than having a pre-ordained self, says Sartre, humans first encounter themselves as already existing in a particular situation. To illustrate this point in "Existentialism Is a Humanism," Sartre contrasts the human condition with that of a paper knife. When we see a paper knife, he says, we see that an artisan conceived its design and use; furthermore, we see that the artisan manufactured it according to known production techniques. All of these factors coalesced before the paper knife came into existence. This coalescence means that the paper knife's essence - its conception and production - preceded its existence.

Having made this point, Sartre notes that a particular view of humanity likewise - and mistakenly - treats humans as if their essence precedes their existence. That view involves God as the creator, the "supernal artisan" (348). If people mistakenly assume that such an artisan exists, says Sartre, then they must likewise mistakenly conclude that human essence necessarily precedes its existence. Interestingly, Sartre sees this same "mistaken" perspective even in purportedly atheistic philosophies of the eighteenth century: statements about "human nature," he says, suggest that each person represents "a particular example of a universal conception, the conception of Man” (348).

Sartre rejects these universalizing views (essence preceding existence) by adopting a particularizing view that focuses on individual 
situations. Sartre labels this view, which eliminates an artisan God, as "atheistic existentialism" (349). By eliminating the artisan, Sartre finds support for the proposition that human existence precedes its essence. Most important, Sartre finds justification for a radical view of human freedom:

Everything is indeed permitted if God does not exist, and man is in consequence forlorn, for he cannot find anything to depend upon either within or outside himself. He discovers forthwith, that he is without excuse. For if indeed existence precedes essence, one will never be able to explain one's action by reference to a given and specific human nature; in other words, there is no determinism man is free, man is freedom. (353)

The foregoing shows how Sartre views people as both absolutely free and absolutely responsible. People are free to create themselves, but they are also "without excuse" - responsible for the choices they make in a meaningless world.

In Caifás, the Jewish leader agrees with Sartre that the world is meaningless. Unlike Sartre, however, Caiaphas does not posit a godless universe. Rather, he concludes that God is effectively absent. Caiaphas does so because he cannot resolve the problem of evil - the coexistence of evil and a just God. In the prologue, for example, Caiaphas attempts to comfort the widowed Martha after her husband's death. The husband (Samuel) was a young and righteous man. When Martha asks Caiaphas why God made her husband die, Caiaphas answers that all people die and that the spirits of the righteous move on to dwell in God's presence. Martha responds that she cannot live without Samuel. Furthermore, she insists that neither she nor Samuel deserves to die. Upon hearing this, Caiaphas gets angry:

CAIAPHAS: Have you searched your heart deeply enough to say something like that, to say that you don't deserve this punishment? Is your life - and Samuel's - so pure and free of sin that you can justify such insolence before your creator? Have you searched your heart to that extent, Martha?

MARTHA: Search it yourself, Your Excellency. Search it yourself and tell me. I have no secrets.

CAIAPHAS: Confused. At any rate, even if your heart was pure, you'd still be the daughter of a woman. And as such you have inherited the sins of your parents. (19) 
In the face of Martha's challenge, "Search it yourself," Caiaphas begins to doubt his own arguments. Nevertheless, he answers Martha's challenge with a traditional response: we die to pay for the sins of Adam and Eve and all those who have lived before us. Furthermore, Caiaphas affirms the justice of God:

CAIAPHAS: It's possible that you don't comprehend it, but God is just. And if he has decided that Samuel should die, you can be sure that he has acted justly.

MARTHA: What do you mean "acted justly"? What kind of justice kills Samuel, the best man on earth, the most humble?

CAIAPHAS: Divine justice.

MARTHA: Well I want human justice. (20)

Martha wants human justice because divine justice appears arbitrary. At least human justice, she reasons, attempts to explain itself logically: a law exists, and one must suffer the consequences for breaking that law. Human justice, therefore, is based upon personal responsibility. Because the divine justice that Caiaphas describes is not based upon personal responsibility, Martha rejects it.

After visiting with Martha, Caiaphas recognizes that he cannot reconcile the coexistence of a just God and death. While Caiaphas repeatedly affirms his belief in God and in an eternal spiritual life, he simultaneously affirms that he cannot justify death. He later discusses the problem with his assistant, Saul. Saul says that he simply believes God is just; Saul explains, however, that he bases his belief on his heart, not on logic. Caiaphas responds that the ability to believe without understanding explains why Saul is a priest. Nevertheless, Caiaphas knows that the people he serves, like the newly widowed Martha, cannot believe without understanding. They need an explanation for life and its suffering that comports with a just God. Such an explanation would satisfy Martha's demand for human justice.

Because Caiaphas becomes convinced that no such explanation exists, he decides to invent his big lie about Jesus as the Messiah. By convincing the Jews that they have killed the Messiah, Caiaphas hopes to create such remorse that his people will accept life's miseries as the punishment of a just God. The Jews will therefore accept God's justice and his involvement in their daily lives. God will no longer be absent to them.

Notwithstanding his effort to make God present to his people, Caiaphas himself sides with Sartre, at least concerning human freedom. Specifically, 
the fact of death clearly convinces Caiaphas that humanity is nothing to God. Furthermore, Caiaphas seems willing to affirm that God is nothing to him, at least as far as his personal choices are concerned. That is, in a twist on Sartre's philosophy, Caiaphas affirms God's existence but insists on his own freedom to act. Caiaphas' final words, a resigned and bitterly ironic form of the Lord's Prayer, illustrate his attitude:

Our Father, who art in heaven, behold our deception: Jesus has died to redeem thee in the poor consciences of men. Behold our scheme to ensure that men could worship thee and find this miserable life more bearable. Go meet them. Go find these poor men who are guided to thee by a lie, yet travel the road of humility, resignation, and repentance. May thy name be blessed among the blessed, and may the works of thy hands be considered just in the eyes of men. Amen. (96)

Caiaphas' bitter prayer reflects his determination to create meaning in a world rendered meaningless by God's absence. The last line of the prayer underscores this determination: "May the works of thy hands be considered just in the eyes of men." Of course, Caiaphas finds no objective reason to believe that God is just. Indeed, he believes the only way his people can consider God just is if they accept the "big lie" about Jesus. That lie provides meaning for Caiaphas' flock. The lie itself, however, means nothing to Caiaphas. Rather, he gives his own life meaning by creating the lie. Creating the lie represents Caiaphas' decision to act on his own: the meaning resides in the action.

While Caiaphas' effort to create meaning reflects existentialist thought, existentialists do not label life meaningless or absurd simply because God seems absent (or dead). Instead, existentialist absurdity flows from the foundation for human choices. Specifically, existentialists argue that unlike plants or rocks, humans have the capacity to care about how they live their lives. Humans, that is, can adopt an attitude toward life, an attitude that Sartre calls a "choice" (Being and Nothingness 480). This attitude or "fundamental choice" (Cooper 143) grounds each person's beliefs about right and wrong, important and unimportant.

The existentialist's "fundamental choice" - the decision to take a stand - makes genuine human existence possible. Sartre asserts that this fundamental choice, however, is itself unjustified. This unjustifiability supports the existentialist premise that life is absurd: 
Precisely here because we are dealing with a choice, this choice as it is made indicates in general other choices as possibles. The possibility of these other choices is neither made explicit nor posited, but it is lived in the feeling of unjustifiability; and it is this which is expressed by the fact of the absurdity of my choice and consequently of my being. (Being and Nothingness 479-80)

While the fundamental choice's unjustifiability supports the claim that life is absurd, unjustifiability does not fully explain existentialist absurdity. Rather, as David Cooper notes, existentialist absurdity flows from the "tension" between the unjustified fundamental choice and "the seriousness of engagement with the world" (143). Cooper cites Thomas Nagel for a lucid description of this tension:

We cannot live human lives without energy and attention, nor without making choices which show that we take some things more seriously than others. Yet we have always available a point of view outside the particular form of our lives, from which the seriousness appears gratuitous. These two inescapable viewpoints collide in us, and that is what makes life absurd. It is absurd because we ignore the doubts that we know cannot be settled, continuing to live with nearly undiminished seriousness in spite of them. (Nagel 14, as cited in Cooper 143)

Living "with nearly undiminished seriousness" despite life's absurdity is the existentialist project. In other words, existentialist thought requires humans to create their own meaning precisely because life is absurd. Creating such meaning, however, requires making choices in a particular way. That way is generally labeled "authenticity" (Guignon 499-500).

"Authenticity" concerns remaining true to the fundamental choice to live "with nearly undiminished seriousness" about one's own existence. People demonstrate their faithfulness, their authenticity, in two ways: 1) by exercising agency according to the guiding principles that flow from the fundamental choice; and 2) by accepting responsibility for exercising agency (Stott 7778). In Caifás, Jesus embodies authenticity. That authenticity appears repeatedly in Jesus' decision-making. The motives behind Jesus' decisions are made obvious, even though Jesus does not actually appear on stage. In the prologue, for example, the widowed Martha sends a boy to find Jesus so that he can raise her husband from the dead. When Jesus and the boy arrive at Martha's door, however, Caiaphas is already there. The following exchange takes place: 
BOY: $\quad$ Martha!

MARTHA: What? Come here.

BOY: $\quad$ Take it. He didn't want it. He returns the piece of jewelry to her. He said that the poor who follow him are rich...or something like that.

MARTHA: Without showing the interest that she would have shown before. He didn't want to come?

BOY: He's here. He's outside at the front door, waiting for you. Martha, surprised, looks at the boy for a second. She then moves to a spot where she can see the front door, which is somewhere stage right and out of the audience's view.

MARTHA: $\quad$ She stares enthralled at the spot where Jesus would be. Is that him?

BOY: $\quad$ Yes.

CAIAPHAS: Martha! She doesn't hear him.

MARTHA: How did you find him so quickly? You just left!

BOY: $\quad$ I don't know...He was coming down the road.

MARTHA: $\quad$ Surprised, but unable to take her eyes off Jesus. He was coming here, then?

BOY: $\quad$ No. I don't know. There were a lot of people with him, but he told them to go away.

CAIAPHAS: Scornfully, looking at Jesus for a moment. And isn't this the one who likes to perform miracles in front of lots of people? Why did he tell them to leave? (25-26)

The answer to Caiaphas' sarcastic question is implicit: Jesus sent his followers away because he did not perform miracles for his own benefit. Furthermore, he refused to keep the jewel Martha had sent as payment. These actions underscore the existentialists' authentic life: acting because we choose to act.

In the context of Caifás, authentic living could be termed "existential redemption." In the play, however, only Jesus and Caiaphas achieve such redemption. Specifically, both Jesus and Caiaphas represent characters who exercise choice and take responsibility for agency, thus redeeming themselves from the inauthentic life of those who confuse their everyday activities with genuine living. That redemption, however, does not necessarily bring happiness. For Jesus, redemption - living the existentialist's authentic life - 
brings death; for Caiaphas, redemption brings bitterness. Nevertheless, the actions of both characters provoke existential questions about how humans engage the world.

\section{Constructing Ideology}

The existentialist questions that the play provokes are set against a backdrop dear to Marxists: the construction of ideology. Indeed, Caiaphas' construction of the "big lie" dovetails easily with Louis Althusser's wellknown description of how ideology works. In "Ideology and Ideological State Apparatuses," Althusser describes how the ruling classes employ ideology to ensure the lower classes' voluntary submission to the existing order. Ideology is successful, says Althusser, because it creates certain "obviousnesses" (171-72). In particular, the "obviousness" that people are subjects - agents capable of acting and taking responsibility for action - "is an ideological effect, the elementary ideological effect" (172). Furthermore, while ideology creates subjects, Althusser notes that the term subject has another meaning: submission to higher authority. Ideology, therefore, creates agents yet also makes them submissive. Specifically, individuals submit to the authority of that which centers ideology: the "Absolute Subject" (180). This center or Absolute Subject will vary depending on what kind of societal structure is involved. The Absolute Subject centering religion, however, is readily identified; that Subject is God.

Althusser asserts that as an Absolute Subject, God creates both subjects and subjection: "[T]hose who have recognized God, and have recognized themselves in Him, will be saved" (180). In essence, the Absolute Subject tells individuals who they are. By recognizing who they are and behaving as the Absolute Subject desires, subjects are guaranteed that "everything will be all right: Amen - 'So be it" (181). The prayer-word "Amen" shows the subjects' belief that reality must exist as religious ideology has constructed it. Althusser argues that all ideology, however, invokes something similar to this "Amen" or "So be it."

In Caifás, the "Amen" appears at the end of the play when the widow Martha exclaims: "No wonder my own son died, since I was killing the Son of God at the time. Now I see! Oh, forgive me, Lord!" (95). Martha's anguished yet paradoxically relieved cry reflects her response to Caiaphas' new ideology. That new ideology allows Martha to reconcile the co-existence of evil (her son's death) and a just God in human terms. Earlier in the play, Martha had demanded "human justice." Caiaphas' new ideology provides 
such justice by affixing a punishment (death) to the crime of killing the Messiah. As Caiaphas hoped, Martha now believes she knows who she is. She now understands that in spite of death, God is just. In fact, she accepts God's justice not in spite of death but rather because of death. Death is simply a just punishment for killing the Son of a just God.

\section{An Existential Framework for Subjectivity and Agency}

\section{A. An Interpretive Paradox}

While Caiaphas' "big lie" hails his flock into the new religious ideology he desires, that ideology simultaneously appears to create an interpretive paradox. That is, Caifás contains a strong claim for achieving existential redemption through agency. Such agency, the ability to make choices and accept responsibility for doing so, appears to imply the existence of autonomous subjects. The very idea of autonomous subjectivity, however, has been severely criticized by anti-humanists like Althusser. As noted previously, Althusser argues that subjectivity is "an ideological effect, the elementary ideological effect" (46). If Althusser is right, then no autonomous subject capable of exercising agency can exist. Indeed, anti-humanists have consistently attacked existentialist accounts of agency on this very basis (Guignon 500). Thus the apparent paradox in Caifás: the play advocates human agency even as the protagonist employs ideology to create the "elementary ideological effect" of subjectivity. How, one asks, can autonomous subjects genuinely exercise agency if subjectivity is simply an "effect"?

B. Situated Subjectivity: Finding a Middle Ground between Humanism and Anti-Humanism

The foregoing question assumes an either/or stance: subjectivity is either autonomous or constructed (an "effect"). This either/or stance reflects the disagreement between humanist and anti-humanist views of subjectivity. Humanists, for example, posit an "unencumbered" (Kruks 7) subjectivity featuring "consciousness" and "agency" (Soper 12). In contrast, postmodern or anti-humanist theorists emphasize the social construction of subjectivity. The social structures or systems of thought that construct subjectivity may be discourse practices (Foucault), the play of signs (Derrida), or ideology (Althusser), but anti-humanists would nevertheless agree that subjectivity is constructed. This anti-humanist notion of purely constructed subjectivity cannot be reconciled with humanism's unencumbered subjectivity.

While one cannot reconcile humanist and anti-humanist views of subjectivity, neither can one consistently choose either view over the other. 
As Sonia Kruks points out, consistently choosing one of these views invites "persuasive criticism from the other" (7). Specifically, strict humanism does not explain the social structures that shape subjectivity, while strict antihumanism never completely eliminates autonomous subjectivity. If one cannot consistently choose either view, however, what option remains? Soper suggests that the "best we can offer" is to affirm the "interdependence" of subjects and structures (151). This answer suggests a middle ground between humanism and anti-humanism, although Soper does not explore the issue further. Kruks, however, does precisely that. She describes this middle ground as "the hypothesis that subjectivity is at once constituting and constituted, that structures (discursive practices, systems of signifiers, or what you will) act and re-act upon each other, so that we must talk of an 'encumbered' subjectivity and 'human' structures" (7). Kruks labels this middle ground "situated subjectivity" (11), a notion based on French existentialism.

The reason existentialists favor situated subjectivity over unencumbered subjectivity lies in what Cooper calls the "main tenet of existential phenomenology": "[N]o sense can be made of mind except as engaged, through embodied activity, in a world which cannot, therefore, be contained 'inside' it" (16). This concept of embodied activity indicates that human beings are always engaged in the world. They act in a time and a place, "always embedded in a situation" (Guignon 496). The world human beings encounter, however, is not the world as viewed by a detached scientific observer. Rather, the world is fundamentally human. Within this human world, we are inextricably intertwined - "always already," in Heidegger's terms (157) - with whatever confronts us. Our choices, therefore, create our experience of the world even as the world informs our choices.

The subjectivity encompassed by the foregoing contrasts deeply with both humanism and anti-humanism. As noted earlier, humanism advocates transparent (constituting) subjectivity, while anti-humanism advocates constructed (constituted) subjectivity. Existentialism's situated subjectivity, however, avoids theses two extremes. Indeed, by noting how our choices create our experience of the world even as the world informs our choices, situated subjectivity reflects "a relation of mutual permeability between subjectivity and its surrounding world" (Kruks 11).

\section{A Divine Jesus As an Allegory of Faith}

Section IV above outlines an interpretive paradox in Caifás. That paradox concerns agency. Specifically, Caifás makes a strong claim for agency even 
as the protagonist employs ideology to create the "elementary ideological effect" of subjectivity. This paradox finds a partial resolution in situated subjectivity. That is, because situated subjectivity posits mutual permeability between subjectivity and the world, the competing ideas in Caifás can coexist to some degree. In other words, situated subjectivity allows human agency even though subjectivity may be shaped by social structures, including ideology. Thus, situated subjectivity provides an avenue to escape Caifás' apparent interpretive paradox. Presumably, however, situated subjectivity could do so for any existentialist work. The value of Caifás, therefore, does not lie in the fact that it is an existentialist work. Rather, the play's value lies in its innovative response to those, like Althusser, who reject the possibility of agency. That response takes the form of an arresting allegory of faith, an allegory that depends on the possibility that the play's Jesus is actually divine. $A$. The Possibility of a Divine Jesus

The possibility of a divine Jesus in Caifás may seem surprising, particularly given the play's scandalous re-imagination of Jesus' passion. Nevertheless, the play contains several clues suggesting that Caiaphas" "big lie" may actually be true. The first such clue appears, as has already been mentioned, in the prologue. Specifically, the newly widowed Martha sends a boy to ask Jesus to come and raise her husband from the dead. The boy returns quickly because Jesus was apparently coming already. The scene strongly suggests that Jesus knew Martha needed him before the boy asked.

Other clues suggesting the Jesus character's divinity appear in the behavior of Judas Iscariot. Judas first appears when he interrupts a conversation between Caiaphas and Saul, the assistant priest. Caiaphas has just told Saul that perhaps the Fall of Adam is simply a myth designed to make people think God is just "in spite of all appearances to the contrary" (Martínez 42). At that moment, Judas appears. He tells Caiaphas that Jesus has committed blasphemy and should therefore be punished. Uninterested, Caiaphas answers that Jesus is simply one in a long line of false prophets. "But this one is more important. This one does miracles," Judas responds (45). Furthermore, Judas continues, he can deliver Jesus for thirty pieces of silver. Both this statement and others Judas makes suggest that Jesus satisfies messianic prophecies:

JUDAS:

All I ask is thirty pieces of silver. It's not much. The priest smiles and turns to look at Caiaphas. Caiaphas understands immediately and bursts into laughter. 
CAIAPHAS: Ha! Ha! Ha! I get it now. Thirty pieces of silver! Just like the scriptures prophesy, right?

JUDAS: I don't understand. I just...

CAIAPHAS: Sure, all you want is thirty pieces of silver for handing this man over to me. You know there's a prophecy in Psalms or Jeremiah...

PRIEST: $\quad$ Right. Jeremiah...

CAIAPHAS: In Jeremiah it says that the Messiah will be handed over for that amount, and you have taken it upon yourself to make sure that the prophecy is fulfilled with this...Jesus. You're doing it so he'll look like the Messiah, right?

JUDAS: . I don't understand you, Your Excellency.

CAIAPHAS: Tell me. How you would you point him out to me? A kiss, perhaps?

JUDAS: Disconcerted. Well, yes.

CAIAPHAS: Transition. You must love him a great deal to sacrifice yourself for him like this. Because I suppose you know the rest of the prophecy as well.

JUDAS: Love him? No. You don't understand. I just want him punished. It's not much, thirty pieces of silver.

CAIAPHAS: Probing. And if I give you fifty?

JUDAS: $\quad$ Thirty would be enough, Your Excellency.

CAIAPHAS: Yes, yes, of course. I understand you very well. I'm sorry, but I won't be a party to your little game. To himself. To actually come to me with this! That they'd actually go so far as to...Incredulously, to Judas. Tell me. Is this man willing to die like the prophecies say? Judas does not answer. Caiaphas takes his silence to be an affirmative response. He talks to himself again. My people certainly are a strange lot! To Judas. Well. Go on now. Get out! You didn't actually think I'd take you up on this, did you? (47-49)

But Caiaphas calls Judas back. Caiaphas does so because he sees that he can create a myth to replace the Adam myth he now distrusts. Believing that Judas is actually in league with Jesus, Caiaphas asks more about Jesus: 
CAIAPHAS: And this man, have the prophecies been fulfilled in him? What I mean is, can you make his life fit the prophecies?

PRIEST: $\quad$ Smiling sarcastically. The lives of all of them do, Master. Caiaphas pays no attention to him.

JUDAS: $\quad$ Yes, Your Excellency. It's a strange coincidence. (50)

The foregoing suggests that Jesus may have fulfilled messianic prophecies even before Caiaphas becomes involved. Indeed, notwithstanding the assistant priest's wry comment, Judas affirms that Jesus' life fits the prophecies. Furthermore, Judas himself unwittingly fulfills prophecy by seeking thirty pieces of silver and planning to identify Jesus with a kiss. The play thus indicates that some prophecies are fulfilled without Caiaphas' intervention.

A scene near the end of the play makes this point rather humorously. The scene once again involves Judas, a rather dim-witted character who never understands that Caiaphas believes they are co-conspirators in a Messiah gambit. In the scene, Caiaphas asks Judas if Jesus' followers know the scriptures sufficiently well to satisfy all messianic prophecies, including "the resurrection, the great storm, the tunic, and the veil of the temple" (7677). Confused, Judas says he does not understand. Caiaphas then gets angry:

CAIAPHAS: Idiot! Don't you know I'm with you, that we're working for the same cause?...No matter how prepared you people are, you can't possibly have my experience in questions of religion or know the scriptures as well as I do. For example, you know that you must kill yourself tonight, don't you?

JUDAS: Backing away and shaking his head. No. No.

CAIAPHAS: Come back, you idiot! Don't go! At least tell me...! Come back, I'm telling you! I command it!

JUDAS: $\quad$ From outside, among the crowd, his voice can be heard. He shouts. Take back your money, Caiaphas! I repent of what I've done! Take it back! He throws the bag of money to Caiaphas.

CAIAPHAS: Smiling and picking up the bag, he talks to himself in a low voice. You repent, do you? And this. That's right; I'd forgotten. That's the way it's written. Feeling the weight of the bag in his hand. 
Off to the potter's field. I guess you people know your scriptures after all. (77-78)

While Judas' words and actions imply that he is unconsciously fulfilling prophecy, another witness to the Jesus character's possible divinity is God himself. Two "miracles" support this conclusion. First, a storm suddenly appears during Jesus' crucifixion. While Caiaphas had been hoping for such a storm (due to prophecy), he had begun to lose hope as the day turned clear. The sudden storm, however, relieves his fears. Saul, the priest, says that the storm "looks like a miracle" (79). The second miracle occurs at the very end of the play. In the final scene, Saul's remorse about helping to promote the big lie makes him turn against Caiaphas. Saul angrily demands a divine sign showing that God approves of the big lie. If no sign appears, Saul threatens, he is going to tell the people the truth. Seconds later, a sign appears in the person of Martha. As noted previously, she enters the temple to complain about her son's death. She leaves, however, saying "Now I see! Oh, forgive me, Lord!" (95). This "miracle" convinces Saul that the big lie has had its intended effect. Indeed, Saul is so convinced that he accepts Caiaphas' command to masquerade as a missionary for the Christian cause.

The foregoing demonstrates that one can make a strong case for Jesus' divinity in the world of the play. Admittedly, none of the points supporting that case is free of ambiguity. Specifically, one can argue that Jesus just happens to be coming down Martha's road when she needs him, that the miracles Judas reports are not really miracles, that Jesus just happens to fit the messianic prophecies (like other charlatans, as the priest Saul says), that Judas just happens to act out the prophesied traitor's role, that a storm just happens to occur during Jesus' death, and that Martha just happens to appear when Saul asks for a sign showing divine approval of the big lie. All of these events could simply be coincidental. But, of course, they may not be coincidental at all.

\section{B. An Allegory of Existential Faith and Agency}

Because Caifás provides no unambiguous proof of Jesus' divinity, faith is required to conclude that the play's Jesus is indeed the Messiah. This need for faith provides an answer to Althusser. Specifically, as noted above, Althusser claims that subjectivity is illusory. Ideology creates that illusion, says Althusser, to mask the real "relationship of individuals to their real conditions of existence" (36). If Althusser is right about subjectivity being illusory, then the agency necessary for living an existentially authentic life is likewise illusory. For Althusser, therefore, the existential redemption advocated 
in Caifás is impossible. The possibility that the play's Jesus really is the Son of God, however, suggests that God has intervened in human life to make authenticity possible. In other words, Caifás provides an allegorical account of human agency. According to Caifás, humans seize agency through faith that they can create a meaningful relationship to the conditions of their existence.

While the Jesus character's possible divinity provides an allegory of faith and agency, that divinity simultaneously raises a question about agency. Specifically, if Caiaphas and Judas were simply following a divine plan, how could they have any agency at all? This question raises the age-old debate concerning the relationship between God's foreknowledge and human freedom. But José de Jesús Martínez, a Marxist and an avowed atheist (Greene 47), is not writing a theological tract. For that reason, an interpretation limiting Jesus' role to the allegorical one suggested above is most convincing.

In the play, Caiaphas recognizes the potential irony of his situation; indeed, he explicitly considers the possibility that Jesus was divine. In a conversation with Saul, Caiaphas describes his thoughts about this matter:

If that Nazarene really had been the Son of God, would I have killed him? Would I have killed him, Saul? Because I love God, but I also love my people. And it pains me to see them suffer and die so miserably. They are good, genuinely good. They are works of God. They are made one by one, with kisses and embraces, with love, during the moment when husband and wife care for each other most. Isn't it our duty to plead for them, to be their advocates? Isn't it our duty to avenge their misery? I don't know what I'd have done if that Nazarene really had been the Son of God. It's pure fantasy to think about it, but I don't know what I would have done. Let's simply be thankful that he was a charlatan and that we've sacrificed him for the glory of God and the good of men. (80)

While Caiaphas claims here that he does not know what he would have done, he protests too much. Indeed, Caiaphas repeatedly says throughout the play that he knows exactly what he is doing. In particular, he says so three times in a row when Saul questions his plan. Caiaphas' certainty reflects his faith that he can create meaning both for himself and for his people.

\section{Conclusion}

Caifás' strong claim for human agency is similar to that of many existentialist works. Indeed, without the play's divine Jesus, Caifás would be 
practically indistinguishable from Sartre's plays. José de Jesús Martínez would certainly have been familiar with Sartre's attempt to reconcile existentialism and Marxism in Critique of Dialectical Reason (1960). In that work and others, Sartre advanced a strong claim for human freedom within historical and social situations (Guignon 497). Sartre's claim, however, was not based on the humanist premise that "the human subject is immediately present to itself as a center of thought and action" (Guignon 500). Rather, Sartre and other existentialists assumed "a relation of mutual permeability between subjectivity and its surrounding world" (Kruks 11). The subjectivity embodied by this view is neither transparent (humanist) nor constructed (anti-humanist). Rather, it occupies a middle ground of "situated subjectivity." This situated subjectivity offers a response to anti-humanists, like Althusser, who have decentered subjectivity such that they cannot account for "the kind of critical thinking they see as central to the postmodern stance" (Guignon 501).

The argument for "situated subjectivity" finds expression in Caifás. Most importantly, however, the play creates an allegory of faith, embodied in the character of Jesus. That faith concerns the possibility of exercising agency and finding redemption from an otherwise meaningless life. In Caifás, characters show that redemption, authenticity, comes only through faith that by exercising agency, they can establish a meaningful relationship with the conditions of their existence. What those conditions are is irrelevant. For Caifás, characters' attitude, their faith, makes agency and authentic life possible.

Brigham Young University

Notes

1 All quotations from the play are my translations.

\section{Works Cited}

Althusser, Louis. "Ideology and Ideological State Apparatuses (Notes toward an Investigation)." "Lenin and Philosophy" and Other Essays. New York and London: Monthly Review Press, 1971: 127-186.

Cooper, David E. Existentialism: A Reconstruction. Oxford: Basil Blackwell, 1990. Greene, Graham. Getting to Know the General. London: The Bodley Head, 1984. 
Guignon, Charles B. "Existentialism." The Routledge Encyclopedia of Philosophy.

Ed. Edward Craig. London: Routledge, 1998.

Heidegger, Martin. The Basic Problems of Phenomenology. 1975. Trans. Albert Hofstradter. Bloomington: Indiana UP, 1982.

Kruks, Sonia. Situation and Human Existence: Freedom, Subjectivity and Society.

Problems of Modern European Thought. London: Unwyn Hyman, 1990.

Martínez, José de Jesús. Teatro de José de Jesús Martínez: Caifás y otras piezas.

San José, Costa Rica: Editorial Universitaria Centroamericana, 1971.

Nagel, Thomas. Mortal Questions. New York: Cambridge UP, 1979.

Quackenbush, L. Howard. "Cuestión de vida y muerte: tres dramas existenciales."

Latin American Theatre Review 8. 1 (Fall 1974): 49-56.

Rodríguez-Sardiñas, Orlando and Carlos Miguel Suárez Radillo. Teatro contemporáneo hispanoamericano. Vol. III. Madrid: Escelicer, 1971.

Sartre, Jean Paul. Being and Nothingness: An Essay on Phenomenological Ontology.

Trans. Hazel E. Barnes. New York: Philosophical Library, 1956.

. Critique of Dialectical Reason. Trans. Alan Sheridan-Smith. London and New York: Verso, 1990.

. "Existentialism Is a Humanism." 1946. Existentialism from Dostoevsky to Sartre. Trans. and ed. Walter Kaufmann. New York: New American Library, 1975:345-69.

Solórzano, Carlos. El teatro hispanoamericano contemporáneo. Vol. II. México City: Fondo de Cultura Económica. 1964.

Soper, Kate. Humanism and Anti-Humanism. Problems of Modern European Thought. London: Hutchinson, 1986.

Stott, Michell. "Of Truth and Passion: Mormonism and Existential Thought." Dialogue: A Journal of Mormon Thought 22.4 (1989): 76-87.

Woodyard, George W. "The Theatre of the Absurd in Spanish America." Comparative Drama 3 (Fall 1969): 186-92. 